\title{
Mineral content is related to antioxidant and antimutagenic properties of grape juice
}

\author{
C. Dani ${ }^{1}$, L.S. Oliboni ${ }^{1}$, D. Pra ${ }^{2}$, D. Bonatto ${ }^{1}$, C.E.I. Santos ${ }^{3}$, \\ M.L. Yoneama ${ }^{3}$, J.F. Dias ${ }^{3}$, M. Salvador ${ }^{1}$ and J.A.P. Henriques ${ }^{1,4}$ \\ ${ }^{1}$ Instituto de Biotecnologia, Universidade de Caxias do Sul, \\ Caxias do Sul, RS, Brasil \\ ${ }^{2}$ Laboratório de Genética e Neurociência, Universidade Católica de Pelotas, \\ Pelotas, RS, Brasil \\ ${ }^{3}$ Instituto de Física, Universidade Federal do Rio Grande do Sul, \\ Porto Alegre, RS, Brasil \\ ${ }^{4}$ Centro de Biotecnologia, Departamento de Biofísica, \\ Universidade Federal do Rio Grande do Sul, Porto Alegre, RS, Brasil
}

Corresponding author: J.A.P. Henriques

E-mail: henriques@cbiot.ufrgs.br

Genet. Mol. Res. 11 (3): 3154-3163 (2012)

Received November 11, 2011

Accepted March 27, 2012

Published September 3, 2012

DOI http://dx.doi.org/10.4238/2012.September.3.4

\begin{abstract}
Grape juices are an important source of food antioxidants. Unfortunately, there is little data about the mineral composition and the antioxidant, mutagenic and antimutagenic activities of grape juice in eukaryote cells. We evaluated the mineral contents ( $\mathrm{Mg}, \mathrm{Ca}, \mathrm{Mn}, \mathrm{Fe}, \mathrm{Cu}, \mathrm{Zn}, \mathrm{Si}, \mathrm{S}, \mathrm{Cl}$ ) of grape juices, the antioxidant, mutagenic and/or antimutagenic activities of the juices in the yeast Saccharomyces cerevisiae, and looked for a possible association between mineral content and antioxidant, mutagenic and/or antimutagenic activities of juice samples. Eight commercial grape juices, four purple (Bordo variety) and four white (Niagara variety), were evaluated. Most of the minerals were in similar concentrations in purple and white grape juices, except for calcium
\end{abstract}


and copper; purple grapes had more calcium content and white grapes had more copper content. All grape juices had important antioxidant and antimutagenic activities in $S$. cerevisiae and prevented the oxidative damage provoked by hydrogen peroxide $(\mathrm{P}<0.05)$. Positive correlations $(\mathrm{P}<0.05)$ were observed between antioxidant and antimutagenic activities and mineral content. In this context, we concluded that the grape juices, white and purple, are an important mineral source, and these contents explain, in part, the important antioxidant and antimutagenic activities.

Key words: Grape juice; Minerals; Antioxidant; Mutagenicity; Antimutagenicity

\section{INTRODUCTION}

Diet plays an important role in the prevention of some diseases related to oxidative stress, such as atherosclerosis and cancer (Halliwell and Gutteridge, 2007). Although the beneficial effects of a moderate intake of wine are well known, information on the antioxidant ability of grape juice is still limited. Grape juices are sources of different antioxidant substances, mainly polyphenols (Dani et al., 2007); therefore, they may be included among the foods with a high antioxidant potential. Studies on grape juice are very relevant since this beverage is widely consumed and has economical importance (Dani et al., 2007). Currently, several types of grape juices are available in the market: white, purple, and rose, both organic and conventional (Dani et al., 2007). Grape juice from Vitis labrusca grapes has many nutrients and bioactive compounds with antioxidant, antimutagenic, anticarcinogenic, and antiteratogenic activities (Dani et al., 2007, 2008a,b). Grape juice produced from Vitis vinifera grapes is a source of various minerals (Olalla et al., 2004). Fortified red wines produced using polyvarietal grapes from a 60- to 70-year-old vineyard were found to contain cadmium $(\mathrm{Cd})$, chromium $(\mathrm{Cr})$, copper $(\mathrm{Cu})$, iron $(\mathrm{Fe})$, nickel $(\mathrm{Ni})$, lead $(\mathrm{Pb})$, vanadium $(\mathrm{V})$, and zinc ( $\mathrm{Zn})$ (Almeida and Vasconcelos, 2003). Interestingly, only one report has been published on the presence of $\mathrm{Zn}$ and $\mathrm{Cu}$ in grape juices from white and red $V$. vinifera grapes (Olalla et al., 2004).

While some minerals are essential for human nutrition (e.g., $\mathrm{Fe}, \mathrm{Cu}, \mathrm{Se}$, and $\mathrm{Zn}$ ), others such as $\mathrm{Cr}, \mathrm{Cd}, \mathrm{Ni}, \mathrm{As}$, and $\mathrm{Pb}$ can induce DNA damage by direct interaction, and some studies have shown that these metals can also induce DNA strand breaks and chromosomal aberrations in cultivated mammalian cells (Hartwig, 1995; Valko et al., 2006), possibly through the formation of reactive oxygen species (ROS) (Rojas et al., 1999; Linder, 2001). Apparently, $\mathrm{Fe}, \mathrm{Cu}, \mathrm{Zn}$, and Se are necessary to maintain genetic stability; however, these minerals can have carcinogenic, mutagenic, and oxidative effects in specific physiological conditions (Zhu et al., 1997; Rojas et al., 1999).

This study is the first to show the mineral composition of purple and white V. labrusca grape juices and its relationship with their biological effects. To achieve this goal, we established the mineral composition of purple and white grape juices by particle-induced X-ray emission (PIXE) and determined their antioxidant, mutagenic, and antimutagenic activities by using Saccharomyces cerevisiae as a biological model. 


\section{MATERIAL AND METHODS}

\section{Grapes and grape juices}

Eight grape juices produced from V. labrusca - 4 Bordo and 4 Niagara varieties, and classified into purple and white grape juices, respectively - were used in this study. Purple juices were hot-extracted using pulp, seeds, and skins (Dani et al., 2007). For white juices, the skin was removed before extraction. Their validity periods were recorded, and the same juices were used during the whole study. Major phenolic compounds isolated from different grape juices are shown in Table 1.

Table 1. Major phenolic compounds from different grape juice.
\begin{tabular}{lccccccc}
\hline Grape juice & \multicolumn{7}{c}{ Mineral content $(\mathrm{mg} / \mathrm{L})$} \\
\cline { 2 - 8 } & Total phenolic content & Catechin & Epicatechin & B1 & B2 & B3 & B4 \\
\hline Purple grape juice & $267.87 \pm 38.30^{*}$ & $49.76 \pm 12.81^{*}$ & $7.96 \pm 3.11$ & $7.71 \pm 1.69^{*}$ & $1.79 \pm 0.45^{*}$ & $17.67 \pm 3.29$ & $2.62 \pm 0.54$ \\
White grape juice & $38.05 \pm 5.42$ & $2.36 \pm 1.09$ & $2.41 \pm 0.78$ & $3.16 \pm 1.03$ & $1.11 \pm 0.39$ & $13.45 \pm 1.50$ & $2.23 \pm 0.33$ \\
\hline
\end{tabular}

Data are reported as means $\pm \mathrm{SE} ; * \mathrm{P}<0.05$ for differences between purple and white grape juice. Dietary reference intake for adult males or females aged 19 to 30 years (Angelova et al., 1999). ND = not defined. Adapted from Dani et al. (2007).

\section{Mineral composition of grape juices}

Mineral contents in grape juices were quantified by means of PIXE analysis (Johansson et al., 1995). Briefly, each sample was positioned in the proton beam by means of an electromechanical system. The characteristic X-rays induced by the proton beam were detected by an HPGe detector from EG \& G (GLP series, EG\&G Ortec, USA), at an energy resolution of $180 \mathrm{eV}$ at $5.9 \mathrm{keV}$. The electronic instruments used included a Telenec 245 amplifier connected to a PCA3 multichannel analyzer (Oxford Instruments, USA) running on a PC-compatible computer system. The GUPIX code (Maxwell et al., 1995) was used for data analysis. The minerals analyzed were $\mathrm{Mg}, \mathrm{Ca}, \mathrm{Mn}, \mathrm{Fe}, \mathrm{Cu}, \mathrm{Zn}, \mathrm{Si}, \mathrm{S}$, and $\mathrm{Cl}$.

\section{Antioxidant activity}

In vivo antioxidant activity was evaluated using the yeast $S$. cerevisiae strain XV18514c (MATa, ade2-2, arg4-17, his1-7, lys 1-1, trp5-48, hom3-10) kindly provided by Dr. R. C. Von Borstel (Genetics Department, Alberta University, Canada). Yeast cell suspensions containing $2 \times 10^{7}$ cells $/ \mathrm{mL}$ (exponential phase) and juices $(20 \%$, v/v) were incubated for 1 $\mathrm{h}$ with or without hydrogen peroxide $\left(75 \mathrm{mM} \mathrm{H}_{2} \mathrm{O}_{2}\right.$ ). After incubation, samples were serially diluted to $2 \times 10^{3}$ cells $/ \mathrm{mL}$ in saline solution $[0.9 \%(\mathrm{w} / \mathrm{v}) \mathrm{NaCl}]$, plated onto YPD $[0.5 \%(\mathrm{w} / \mathrm{v})$ yeast extract, $2 \%(\mathrm{w} / \mathrm{v})$ bacto-peptone, $2 \%(\mathrm{w} / \mathrm{v})$ glucose, and $2 \%(\mathrm{w} / \mathrm{v})$ bacto-agar for solid medium], and incubated at $28^{\circ} \mathrm{C}$ for $48 \mathrm{~h}$. Colonies were then counted and compared with those obtained on control plates, which were assumed to represent $100 \%$ of yeast cell survival.

\section{Mutagenic and antimutagenic activities of grape juices}

The yeast strain XV185-14c was also used for mutagenic and antimutagenic assays. 
Complete YPD medium, containing $0.5 \%$ yeast extract, $2 \%$ bacto-peptone, and $2 \%$ glucose, was used for the routine growth of the yeast cells. The minimal medium (MM) contained $0.67 \%$ yeast nitrogen base with no amino acids, $2 \%$ glucose, and 2\% bacto-agar and was supplemented with the appropriate amino acids. The synthetic complete (SC) medium was MM supplemented with $2 \mathrm{mg}$ adenine, $2 \mathrm{mg}$ arginine, $5 \mathrm{mg}$ lysine, $1 \mathrm{mg}$ histidine, $2 \mathrm{mg}$ leucine, $2 \mathrm{mg}$ methionine, 2 $\mathrm{mg}$ uracil, $2 \mathrm{mg}$ tryptophan, and $24 \mathrm{mg}$ threonine per $100 \mathrm{~mL}$ MM. Exponential-phase cultures were obtained by inoculating $5 \times 10^{6}$ cells $/ \mathrm{mL}$ of a stationary-phase YPD culture into fresh YPD medium for $3 \mathrm{~h}$. Before treatment with grape juice (10 and 50\%, v/v), cells in each culture were harvested, washed twice with $20 \mathrm{mM}$ phosphate-buffered saline solution (PBS; $\mathrm{Na}_{2} \mathrm{HPO}_{4}$, and $\mathrm{NaH}_{2} \mathrm{PO}_{4}, \mathrm{pH}$ 7.4), and examined for budding cell percentage.

All yeast assays were repeated at least 4 times, and plating was performed in triplicate for each dose. The positive control was a solution containing $5 \mu \mathrm{M}$ 4-nitroquinoline-1-oxide (NQO) and $50 \mathrm{mM} \mathrm{H} \mathrm{H}_{2}$. Survival was determined by colony counting in the $\mathrm{SC}$ medium [containing $0.67 \%$ yeast nitrogen base with no amino acids, $2 \%$ glucose, $2 \%$ bacto-agar, and $0.25 \%\left(\mathrm{NH}_{4}\right)_{2} \mathrm{SO}_{4}$ ] for 3-5 days, at $28^{\circ} \mathrm{C}$.

A suspension of $2 \times 10^{8}$ cells $/ \mathrm{mL}$ in stationary or exponential growth phase was incubated in PBS for mutagenic evaluation under non-growth conditions, or the suspension was incubated in liquid YPD for mutagenic evaluation under growth conditions, with different concentrations $(10$ and $25 \%, v / v)$ of white and purple grape juices at $30^{\circ} \mathrm{C}$ for $3 \mathrm{~h}$. Antimutagenic assay was also performed with the same yeast strain, by cotreating cells with $10 \%$ grape juices and $50 \mathrm{mM} \mathrm{H}_{2} \mathrm{O}_{2}$ for $4 \mathrm{~h}$ at $28^{\circ} \mathrm{C}$ with shaking. Samples were plated onto SC, SC-his, SC-lys, and SC-hom media. Hydrogen peroxide $(50 \mathrm{mM})$ was used as the positive control. Plating was done in triplicate for each dose. While his 1-7 is a non-suppressible missense allele, and reversions result from mutation at the locus itself, lys $1-1$ is a suppressible ochre nonsense mutant allele, which can be reverted either by locus-specific or by forward mutation in a suppressor gene. True reversions and forward (suppressor) mutations at the lys 1-1 locus were differentiated according to Schuller and von Borstel (1974), where the reduced adenine content of the SC-lys medium shows locus reversions as red colonies, and suppressor mutations as white colonies. It is believed that hom3-10 contains a frameshift mutation due to its response to a series of diagnostic mutagens.

\section{Statistical analyses}

Values were determined as parametric or non-parametric by using the Kolmogorov-Smirnoff test. Data were subjected to analysis of variance (ANOVA), and means were compared using the Tukey test. Groups were compared by the Student $t$-test and the Mann-Whitney U-test. Relationships between variables were assessed by using Pearson's product-moment correlation coefficient.

\section{RESULTS AND DISCUSSION}

The effect of grape-based products, such as wines and grape-seed extracts, on health has been well established, with emphasis on polyphenol compounds (Bagchi et al., 2000). Although minerals can be as effective as vitamins and phenolic compounds in exerting beneficial health effects when in appropriate levels, few studies thus far have addressed the benefits of metals in biological systems. Therefore, to our knowledge, this is the first study to show the level of metals and their relationship with the antioxidant and antimutagenic activity of grape juices produced from the Bordo 
and Niagara cultivars of $V$. labrusca. A previous report addressed the $\mathrm{Cu}$ and $\mathrm{Zn}$ levels in grape juices extracted from $V$. vinifera (Olalla et al., 2004) and indicated the need for further studies.

The results of mineral content by PIXE analysis showed that purple and white grape juices had distinct mineral profiles (Table 2). Purple grape juices had significantly higher levels of $\mathrm{Cl}$ and $\mathrm{Mg}$ when compared to white grape juices (Table 2). On the other hand, $\mathrm{Cu}$ concentration was higher in white grape juices than in the purple ones (Table 2).

Table 2. Mineral composition of the grape juices evaluated.

\begin{tabular}{lccccccccc}
\hline Grape juice & \multicolumn{10}{c}{ Mineral content $(\mathrm{mg} / \mathrm{L})$} \\
\cline { 2 - 8 } & $\mathrm{Mg}$ & $\mathrm{Ca}$ & $\mathrm{Mn}$ & $\mathrm{Fe}$ & $\mathrm{Cu}$ & $\mathrm{Zn}$ & $\mathrm{Si}$ & $\mathrm{S}$ \\
\hline Purple grape juice & $10.70 \pm 0.03$ & $12.88 \pm 1.36$ & $0.36 \pm 0.05$ & $2.18 \pm 0.89$ & $0.58 \pm 0.19$ & $0.77 \pm 0.18$ & $1.09 \pm 0.14$ & $2.36 \pm 0.09$ & $3.00 \pm 0.06$ \\
White grape juice & $10.38 \pm 0.25$ & $7.45 \pm 0.22^{*}$ & $0.28 \pm 0.02$ & $2.23 \pm 0.04$ & $2.41 \pm 1.33^{*}$ & $1.29 \pm 0.30$ & $1.15 \pm 0.10$ & $2.26 \pm 0.12$ & $2.77 \pm 0.12$ \\
DRI & 350 & 1000 & $1.8^{\mathrm{s}-2.3^{*}}$ & $8^{*}-18^{\mathrm{s}}$ & 0.9 & $8^{*}-11^{\mathrm{s}}$ & $\mathrm{ND}$ & $\mathrm{ND}$ & $\mathrm{ND}$ \\
\hline
\end{tabular}

Data are reported as means $\pm \mathrm{SD} ; * \mathrm{P}<0.05$ for differences between purple and white grape juice. $\mathrm{DRI}=$ dietary reference intake for adult males or females $^{\$}$ aged 19 to 30 years (USDA, 2009). ND = not defined.

These results are similar to those found by Ollala et al. (2004), who evaluated grape juices produced from $V$. vinifera. According to Angelova et al. (1999), the difference observed between the grapes is strongly related to the soil type and agricultural practices involved. This is evident from the fact that Ollala et al. (2004) observed that purple grape juice had higher Zn content than white juice ( $V$. vinifera), which was not observed in our study (Table 2).

The $\mathrm{Cu}$ level observed in the present study, particularly in white V. labrusca juice, was higher than those reported by most studies, as summarized in Table 3, but lower than that found in a Brazilian V. vinifera juice (Pinheiro et al., 2009). This difference could be explained by the different varieties of grapes used, soil characteristics, and the application/non-application of Bordeaux mixture, a mixture of copper sulfate and hydrated lime that has been used as a fungicide in vineyards since old days. This aspect deserves further attention in future studies (Onianwa et al., 1999; Olalla et al., 2004).

Table 3. Comparative content of copper and zinc in different grape juices.

\begin{tabular}{lccc}
\hline Grape juice & $\mathrm{Cu}(\mathrm{mg} / \mathrm{L})$ & $\mathrm{Zn}(\mathrm{mg} / \mathrm{L})$ & Reference \\
\hline Purple (Vitis vinifera) & 0.05 & 0.55 & Ollala et al., 2004 \\
Purple (Vitis labrusca) & 0.58 & 0.77 & Table 1 \\
White (Vitis vinifera) & 0.06 & 0.41 & Ollala et al., 2004 \\
White (Vitis labrusca) & 2.41 & 1.29 & Table 1 \\
Non-informed variety (Nigeria) & $0.001-0.27$ & $0.23-1.96$ & 0.75 \\
Non-informed variety (USA) & 0.19 & $9.56 \pm 1.61$ & Onianwa et al., 1999 \\
Purple (Vitis vinifera) (Brazil) & $4.74 \pm 2.83$ & $0.23-9.56$ & Angelova et al., 1999 \\
Range & $0.001-4.74$ & Pinheiro et al., 2009 \\
\hline
\end{tabular}

The mineral profile of grapes and grape juices has been considered important not only from the nutritional aspect but also from a technological point of view. Some minerals may influence the production process, sometimes negatively via an oxi-reduction reaction and/or organoleptic alteration in the grape derivates (Olalla et al., 2004). From the nutritional point of view, grape juices appear to contain relevant levels of some compounds, such as enzyme cofactors and plasmatic membrane stabilizers, which are known to be important to many physiological func- 
tions of the human body (Halliwell and Gutteridge, 2007). According to the National Research Council, Recommended Dietary Allowances - DRI (Onianwa et al., 1999), it is possible to affirm that the daily intake of $500 \mathrm{~mL}$ (about 2 cups) of grape juice from V. labrusca is capable of supplying $7-14 \%$ of the iron, $4-8 \%$ of the manganese, $6-9 \%$ of the zinc, and more than $100 \%$ of the copper needed daily by adults between 19 and 30 years of age, depending on their gender.

Metals are introduced into our environment both from natural and anthropogenic sources. Moreover, metals are ingested daily by humans as part of their diet. For instance, cadmium is present in spinach and cauliflower, while lead is found in Brussels sprouts and Chinese beets. Seafood, such as oysters and fish, commonly contain $\mathrm{Pb}, \mathrm{Cd}, \mathrm{Hg}$, and $\mathrm{As}$. Several trace elements, such as $\mathrm{Cr}$, Se, and $\mathrm{Zn}$, are required for the nutritional well-being of humans and animals. Recent studies suggest that ultra-trace elements, such as As and Ni, may also play a role both in animal and human nutrition (Rojas et al., 1999). Interestingly, the results of the present study indicate that grape juice contains undetectable levels of such harmful metals, suggesting that grape juice is not likely to be a source of toxic metals. Although a glass of grape juice can provide more than $100 \%$ of the daily reference intake of copper, the amount provided is much lower than $10 \mathrm{mg} /$ day, which is the upper limit of the level that can be safely ingested daily by adults (Mahan and Scott-Stumpf, 2004).

The antioxidant, mutagenic, and antimutagenic effects of white and purple grape juices and a possible correlation with mineral content were analyzed by employing the yeast $S$. cerevisiae. Many studies used $S$. cerevisiae as an important model to evaluate the antioxidant (Soares et al., 2003; Mahan and Scott-Stumpf, 2004; Wilsem et al., 2005; Belinha et al., 2007), mutagenic, and antimutagenic activities of different compounds and elements present in foods.

The highest non-cytotoxic concentration $[20 \%(\mathrm{v} / \mathrm{v})]$ of grape juice was used in the in vivo antioxidant assay. All juices showed significant antioxidant activity, decreasing or preventing $\mathrm{H}_{2} \mathrm{O}_{2}$-induced oxidative damage (Figure 1). White juices exhibited a higher protective effect than purple juices and the positive control (Figure 1). When analyzing only the purple

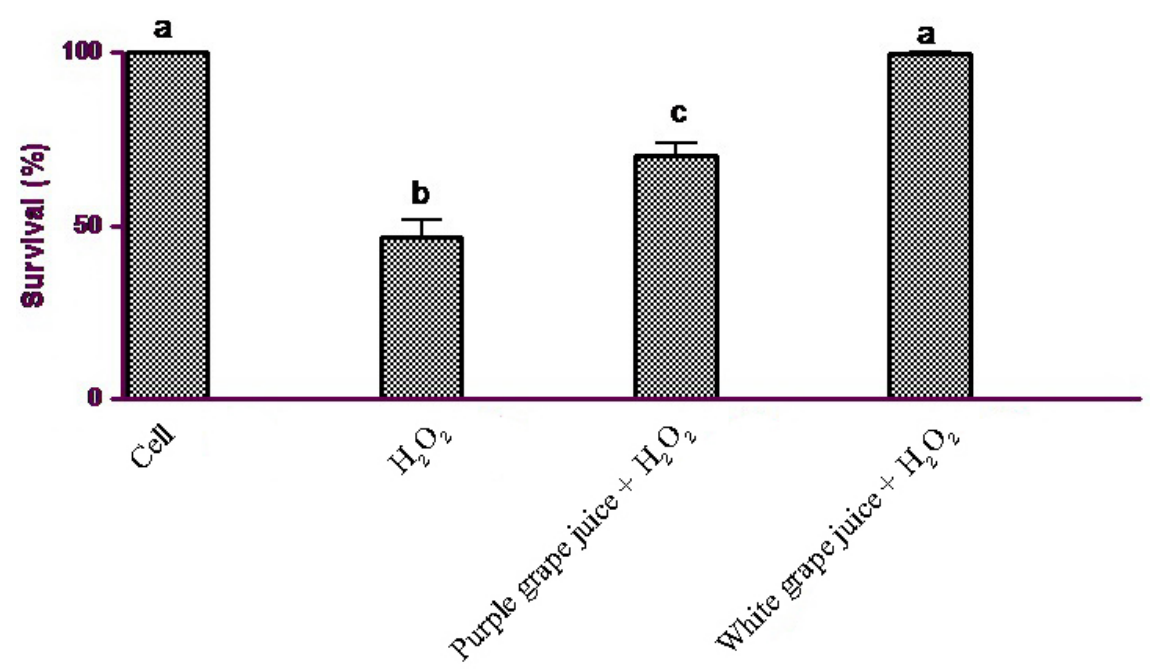

Figure 1. Survival (\%) of the yeast Saccharomyces cerevisiae treated with hydrogen peroxide at $75 \mathrm{mM}$ in the presence or absence of different grape juices $(20 \%, \mathrm{v} / \mathrm{v})$. *Different letters are significantly statistical differences, $\mathrm{P}<0.05$. 
grape juices, we observed that the antioxidant activity showed a positive correlation with $\mathrm{Cu}$ $(\mathrm{R}=0.785, \mathrm{P}<0.05)$ and a negative correlation with $\mathrm{Mg}$ contents $(\mathrm{R}=-0.982, \mathrm{P}<0.01$; Table 4). No correlation between mineral content and antioxidant protection was observed in white grape juice (Table 5). The mutagenic assay was performed by using 2 grape juice concentrations $[10$ and $25 \%(\mathrm{v} / \mathrm{v})]$. None of the analyzed grape juices presented mutagenic activity at any concentration (Table 6).

Table 4. Correlations between antioxidant and antimutagenic activities and mineral composition in purple grape juices.

\begin{tabular}{|c|c|c|c|c|c|c|}
\hline Correlation & $\mathrm{Mg}$ & $\mathrm{Mn}$ & $\mathrm{Cu}$ & $\mathrm{Si}$ & $\mathrm{S}$ & $\mathrm{Cl}$ \\
\hline In vivo antioxidant activity & $-0.982 * *$ & $0.785^{*}$ & $0.785^{*}$ & $\mathrm{NC}$ & $\mathrm{NC}$ & $\mathrm{NC}$ \\
\hline Antimutagenic activity (Lys) & $\mathrm{NC}$ & $0.761 *$ & $0.761^{* *}$ & $-0.828 * *$ & $-0.761 *$ & $-0.761^{*}$ \\
\hline Antimutagenic activity (His) & $0.908 * *$ & $-0.859^{*}$ & $-0.859 * *$ & $0.737^{*}$ & $\mathrm{NC}$ & $\mathrm{NC}$ \\
\hline Antimutagenic activity (Hom) & $-0.781 * *$ & $0.976 * *$ & $0.976^{* *}$ & $-0.926 * *$ & $-0.781 * *$ & $-0.781 *$ \\
\hline
\end{tabular}

Numbers indicate the $\mathrm{r}$ value; $* \mathrm{P}<0.05, * * \mathrm{P}<0.01 ; \mathrm{NC}=$ no correlation.

Table 5. Correlations between antimutagenic activities and mineral composition in white grape juices.

\begin{tabular}{lcccccc}
\hline Correlation & $\mathrm{Mg}$ & $\mathrm{Cu}$ & $\mathrm{Zn}$ & $\mathrm{Si}$ & $\mathrm{S}$ & $\mathrm{Mg}$ \\
\hline Antimutagenic activity (Lys) & $\mathrm{NC}$ & $\mathrm{NC}$ & $0.741^{*}$ & $\mathrm{NC}$ & $\mathrm{NC}$ & $\mathrm{NC}$ \\
Antimutagenic activity (His) & $0.781^{*}$ & $\mathrm{NC}$ & $\mathrm{NC}$ & $\mathrm{NC}$ & $\mathrm{NC}$ & $0.781^{*}$ \\
Antimutagenic activity (Hom) & $-0.781^{*}$ & $0.781^{*}$ & $\mathrm{NC}$ & $-0.781^{* *}$ & $-0.781^{* *}$ & $-0.781^{*}$ \\
\hline
\end{tabular}

Numbers indicate the $\mathrm{r}$ value; $* \mathrm{P}<0.05, * * \mathrm{P}<0.01 ; \mathrm{NC}=$ no correlation.

Table 6. Induction of point mutation (his 1-7), ochre allele (lys 1-1), and frameshift mutation (hom 3-10) in the exponential growth phase of cells of the Saccharomyces cerevisiae strain XV185-14C after treatment with the juices $(10 \%, \mathrm{v} / \mathrm{v})$ for $3 \mathrm{~h}$.

\begin{tabular}{|c|c|c|c|c|}
\hline Samples $^{\#}$ & Survival (\%) & His $1 / 10^{7}$ survivors $^{\mathrm{a}}$ & Lys $1 / 10^{7}$ survivors $^{\mathrm{a}}$ & Hom $3 / 10^{7}$ survivors \\
\hline 0 & $100.0(234)^{\mathrm{c}}$ & $9.82 \pm 1.54^{\mathrm{d}}(69)$ & $7.11 \pm 1.61(50)$ & $3.54 \pm 0.22(25)$ \\
\hline Purple grape juice & $86.82(209)$ & $9.72 \pm 1.0(70)$ & $5.65 \pm 0.61(39)$ & $3.96 \pm 0.47(28)$ \\
\hline White grape juice & $92.0(220)$ & $6.62 \pm 1.60(44)$ & $6.71 \pm 0.78(49)$ & $2.92 \pm 0.62(21)$ \\
\hline
\end{tabular}

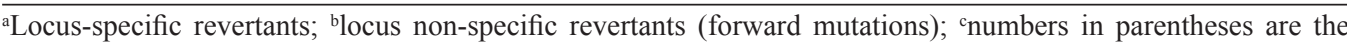
actual numbers of colonies scored in three plates for each dose; ${ }^{\mathrm{d}}$ mean and standard deviation of three independent experiments. Values of the positive control 4NQO $(5 \mu \mathrm{M})$ locus hys $(16.01 \pm 0.05)$, locus lys $(16.25 \pm 2.48)$, and locus homo $(18.51 \pm 4.13)$.

The antimutagenic effects of the grape juices against $\mathrm{H}_{2} \mathrm{O}_{2}$ in yeast are show in Table 7. The juices, purple and white, in cotreatment showed an important antimutagenic potential; in all media (without his, lis, or hom) an important reduction in mutagenicity induced by $\mathrm{H}_{2} \mathrm{O}_{2}$ was observed. In addition, we found an important correlation between mineral content and antimutagenic activities (Tables 4 and 5). When analyzing only the purple grape juices, we observed a positive correlation between antimutagenic activity for lys locus with $\mathrm{Cu}$ and $\mathrm{Mn}$ $(\mathrm{R}=0.761, \mathrm{P}<0.01)$. For the same locus, $\mathrm{Cl}, \mathrm{Si}$ and $\mathrm{S}$ contents showed a negative correlation with antimutagenic activity $(\mathrm{R}=-0.761 ;-0.828 ;-0.761, \mathrm{P}<0.05$, respectively). Negative correlations between antimutagenic activity and $\mathrm{Cl}, \mathrm{Si}$ and $\mathrm{S}$ were observed in the lys and hom loci (Table 4). When considering only white grape juices, a negative correlation was noted 
between antimutagenic activity (hom locus) and $\mathrm{Si}, \mathrm{S}$, and $\mathrm{Mg}$ contents. A positive correlation was observed between antimutagenic activity (lys locus) and $\mathrm{Zn}$ content $(\mathrm{R}=0.741, \mathrm{P}<0.05)$, antimutagenic activity (his locus) and $\mathrm{Mg}$ content $(\mathrm{R}=0.781, \mathrm{P}<0.05)$, and antimutagenic activity (hom locus) and $\mathrm{Cu}$ content $(\mathrm{R}=0.781, \mathrm{P}<0.05)$ (Table 4$)$.

Table 7. Induction of point mutation (his 1-7), ochre allele (lys 1-1), and frameshift mutation (hom 3-10) in the exponential growth phase of cells of the Saccharomyces cerevisiae strain XV185-14C after co-treatment with the juices $(10 \%, v / v)$ and $50 \mathrm{mM}$ hydrogen peroxide $\left(\mathrm{H}_{2} \mathrm{O}_{2}\right)$ for $3 \mathrm{~h}$.

\begin{tabular}{|c|c|c|c|c|}
\hline Samples & Survival (\%) & His $1 / 10^{7}$ survivors $^{\mathrm{a}}$ & Lys $1 / 10^{7}$ survivors $^{\mathrm{a}}$ & Hom $3 / 10^{7}$ survivors $^{\mathrm{b}}$ \\
\hline 0 (Control) & 100.0 & $1.58 \pm 0.83$ & $0.70 \pm 0.35$ & $1,08 \pm 0,48$ \\
\hline $\mathrm{H}_{2} \mathrm{O}_{2}(50 \mathrm{mM})$ & 45.0 & $24.70 \pm 1.09 *$ & $3.18 \pm 1.14^{*}$ & $5.74 \pm 0.66^{*}$ \\
\hline Purple grape juice $(10 \%)+\mathrm{H}_{2} \mathrm{O}_{2}$ & 86.9 & $5.78 \pm 1.65^{*}, * *$ & $2.02 \pm 0.80 *, * *$ & $2.84 \pm 0.84 *, * *$ \\
\hline White grape juice $(10 \%)+\mathrm{H}_{2} \mathrm{O}_{2}^{2}$ & 88.6 & $2.94 \pm 1.10 * * *$ & $0.80 \pm 0.23^{* *}$ & $2.14 \pm 0.34 *, * *$ \\
\hline
\end{tabular}

${ }^{a}$ Locus-specific revertants; blocus non-specific revertants (forward mutations). *Values statistically different in relation to the control by ANOVA and Tukey post-test, for $\mathrm{P}<0.05$. **Values statistically different in relation to $\mathrm{H}_{2} \mathrm{O}_{2}$ by ANOVA and Tukey post-test, for $\mathrm{P}<0.01$.

A previous study on orange juices (Franke et al., 2006) showed that $\mathrm{Cu}$ content was negatively correlated with DNA damage. In addition, $\mathrm{Zn}$ has been reported to be a component of more than 70 different enzymes with various functions in cell metabolism involving the metabolism of proteins, lipids, and carbohydrates (Parkin, 2004); it has also been reported to possess antioxidant activity and decrease ROS production (Jemai et al., 2007). Some studies have reported the ability of $\mathrm{Zn}$ to interact with essential elements, such as $\mathrm{Cu}$ and $\mathrm{Fe}$, and decrease their content in tissues and retard the oxidative processes (Santon et al., 2003).

Similarly, $\mathrm{Cl}$ content showed a negative correlation with the antimutagenic activity of purple grape juice. In some situations, the $\mathrm{Cl}^{-}$ion has been reported to form a complex with hydroxyl radicals and form hypochlorous acid $(\mathrm{HOCl})$, which induces considerable damage to the cells (Halliwell and Gutteridge, 2007). Thus, the negative correlation observed between antioxidant and antimutagenic activity and Si content can be partially explained by the fact that this mineral can form free radicals ( $\mathrm{Si}^{-}$and $\mathrm{SiO}$ ) (Halliwell and Gutteridge, 2007) that induce the peroxidation of unsaturated fatty acids, phospholipids, glycolipids, sterols, amino acids, and sulfhydryl groups of transmembrane proteins (Ghio et al., 1990). Mn content showed contradictory effects; we observed both negative and positive correlations between this mineral and the antimutagenic activity of grape juices. Mn can act as both pro- and antioxidant, and the oxidative-stress-related effects of $\mathrm{Mn}$ are dependent not only on the intracellular concentrations of the metal but also on the exposure duration, secondary oxidative challenges, and overall oxidant-buffering ability of the cells (Worley et al., 2002).

Although the influence of minerals on the physiology of the yeast cells should be extensively studied, our results demonstrate that the antioxidant and antimutagenic properties of wine may be attributed to its mineral contents (Salvo et al., 2003). In conclusion, grape juices obtained from $V$. labrusca cultivars are a good source of micronutrients, which exhibit a correlation with antioxidant and antimutagenic effects of grape juices, and thereby contribute to the prevention of some diseases caused by oxidative stress, such as atherosclerosis and cancer, and neurodegenerative diseases, such as Parkinson's. 


\section{ACKNOWLEDGMENTS}

Research supported by Universidade de Caxias do Sul (Caxias do Sul, Rio Grande do Sul, Brazil), CAPES, IBRAVIN, CNPq, and FAPERGS.

\section{REFERENCES}

Almeida CM and Vasconcelos MT (2003). Multielement composition of wines and their precursors including provenance soil and their potentialities as fingerprints of wine origin. J. Agric. Food Chem. 51: 4788-4798.

Angelova VR, Ivanov AS and Braikov DM (1999). Heavy metals (Pb, Cu, Zn and Cd) in the system soil - grapevine grape. J. Sci. Food Agric. 79: 713-721.

Bagchi D, Bagchi M, Stohs SJ, Das DK, et al. (2000). Free radicals and grape seed proanthocyanidin extract: importance in human health and disease prevention. Toxicology 148: 187-197.

Belinha I, Amorim MA, Rodrigues P, de Freitas V, et al. (2007). Quercetin increases oxidative stress resistance and longevity in Saccharomyces cerevisiae. J. Agric. Food Chem. 55: 2446-2451.

Dani C, Oliboni LS, Vanderlinde R, Bonatto D, et al. (2007). Phenolic content and antioxidant activities of white and purple juices manufactured with organically - or conventionally-produced grapes. Food Chem. Toxicol. 45: 2574-2580.

Dani C, Pasquali MA, Oliveira MR, Umezu FM, et al. (2008a). Protective effects of purple grape juice on carbon tetrachloride-induced oxidative stress in brains of adult Wistar rats. J. Med. Food 11: 55-61.

Dani C, Oliboni LS, Pasquali MA, Oliveira MR, et al. (2008b). Intake of purple grape juice as a hepatoprotective agent in Wistar rats. J. Med. Food 11: 127-132.

Franke SI, Pra D, Giulian R, Dias JF, et al. (2006). Influence of orange juice in the levels and in the genotoxicity of iron and copper. Food Chem. Toxicol. 44: 425-435.

Ghio AJ, Kennedy TP, Schapira RM, Crumbliss AL, et al. (1990). Hypothesis: is lung disease after silicate inhalation caused by oxidant generation? Lancet 336: 967-969.

Halliwell B and Gutteridge JMC (2007). Free Radicals in Biology and Medicine. 4th edn. Clarendon Press, Oxford.

Hartwig A (1995). Current aspects in metal genotoxicity. Biometals 8: 3-11.

Jemai H, Messaoudi I, Chaouch A and Kerkeni A (2007). Protective effect of zinc supplementation on blood antioxidant defense system in rats exposed to cadmium. J. Trace Elem. Med. Biol. 21: 269-273.

Johansson SAE, Campbell JL and Malmqvist KG (1995). Particle-Induced X-Ray Emission Spectrometry (PIXE). John Wiley \& Sons, New York.

Linder MC (2001). Copper and genomic stability in mammals. Mutat. Res. 475: 141-152.

Mahan LK and Scott-Stumpf S (2004). Krause's Food, Nutrition and Diet Therapy. 11th edn. Elsevier Inc, New York.

Maxwell JA, Teesdale WJ and Campbell JL (1995). The Guelph PIXE software package II. Nucl. Instrum. Meth. Phys. Res. Sect. B. 95: 407-421.

Olalla M, Fernandez J, Cabrera C, Navarro M, et al. (2004). Nutritional study of copper and zinc in grapes and commercial grape juices from Spain. J. Agric. Food Chem. 52: 2715-2720.

Onianwa PC, Adetola IG, Iwegbue CMA, Ojo MF, et al. (1999). Trace heavy metals composition of some Nigerian beverages and food drinks. Food Chem. 66: 275-279.

Parkin G (2004). Synthetic analogues relevant to the structure and function of zinc enzymes. Chem. Rev. 104: 699-767.

Pinheiro ES, da Costa JMC, Clemente E, Machado PHS, et al. (2009). Physical chemical and mineral stability of grape juice obtained by steam extraction. Rev. Cienc. Agron. 40: 373-380.

Rojas E, Herrera LA, Poirier LA and Ostrosky-Wegman P (1999). Are metals dietary carcinogens? Mutat. Res. 443: 157-181.

Salvo F, La Pera L, Di Bella G, Nicotina M, et al. (2003). Influence of different mineral and Organic pesticide treatments on $\mathrm{Cd}(\mathrm{II}), \mathrm{Cu}(\mathrm{II}), \mathrm{Pb}(\mathrm{II})$, and $\mathrm{Zn}(\mathrm{II})$ contents determined by derivative potentiometric stripping analysis in Italian white and red wines. J. Agric. Food Chem. 51: 1090-1094.

Santon A, Irato P, Medici V, D'Inca R, et al. (2003). Effect and possible role of Zn treatment in LEC rats, an animal model of Wilson's disease. Biochim. Biophys. Acta 1637: 91-97.

Schuller RC and von Borstel RC (1 974). Spontaneous mutability in yeast. I. Stability of lysine reversion rates to variation of adenine concentration. Mutat. Res. 24: 17-23.

Soares DG, Andreazza AC and Salvador M (2003). Sequestering ability of butylated hydroxytoluene, propyl gallate, resveratrol, and vitamins $\mathrm{C}$ and $\mathrm{E}$ against ABTS, DPPH, and hydroxyl free radicals in chemical and biological systems. J. Agric. Food Chem. 51: 1077-1080.

USDA (US Department of Agriculture, Agricultural Research Service) (2009). USDA National Nutrient Database for 
Standard Reference, Release 22. Nutrient Data Laboratory Home Page. Available at [http://www.ars.usda.gov/ba/ bhnrc/ndl]. Accessed October 2010.

Valko M, Rhodes CJ, Moncol J, Izakovic M, et al. (2006). Free radicals, metals and antioxidants in oxidative stressinduced cancer. Chem. Biol. Interact. 160: 1-40.

Wilmsen PK, Spada DS and Salvador M (2005). Antioxidant activity of the flavonoid hesperidin in chemical and biological systems. J. Agric. Food Chem. 53: 4757-4761.

Worley CG, Bombick D, Allen JW, Suber RL, et al. (2002). Effects of manganese on oxidative stress in CATH.a cells. Neurotoxicology 23: 159-164.

Zhu J, Koken MH, Quignon F, Chelbi-Alix MK, et al. (1997). Arsenic-induced PML targeting onto nuclear bodies: implications for the treatment of acute promyelocytic leukemia. Proc. Natl. Acad. Sci. U. S. A. 94: 3978-3983. 